\title{
Effect of Dates of Sowing and Haulm Cutting on Seed Yield and Quality of Fodder Cowpea
}

\author{
Basavaraj Benachinamaradi*, Vinod Kumar, K. Sridhar and D.S. Uppar \\ Department of Seed Science and Technology, University of Agricultural Sciences, \\ Dharwad - 580 005, Karnataka, India \\ *Corresponding author
}

\section{Keywords}

Dates of sowing,

Haulm cutting,

Fodder cowpea

Article Info

Accepted:

04 June 2019

Available Online:

10 July 2019

\section{A B S T R A C T}

A field experiment was conducted during kharif 2017 at ICAR- Indian Grassland and Fodder Research Institute, Southern Regional Research Station, Dharwad to study the effect of dates of sowing and haulm cutting on seed yield and quality of fodder cowpea. The treatments imposed include three dates of sowing $\left(\mathrm{S}_{1}\right.$ : Sown on June $15^{\text {th }}, \mathrm{S}_{2}$ : Sown on July $15^{\text {th }}$ and $S_{3}$ : Sown on August $\left.15^{\text {th }}\right)$ and four levels of cutting $\left(C_{1}\right.$ : No cutting, $C_{2}$ : Haulm cutting at flower initiation, $\mathrm{C}_{3}$ : Haulm cutting at five days after flower initiation and $\mathrm{C}_{4}$ : Haulm cutting at ten days after flower initiation). The results revealed that, significantly higher pods per plant (17.30), pod length $(16.01 \mathrm{~cm})$, pod weight $(31.07 \mathrm{~g}), 100$ seed weight $(11.00 \mathrm{~g})$ and seed yield $\left(4.29 \mathrm{q} \mathrm{ha}^{-1}\right)$ was noticed in $15^{\text {th }}$ June sowing with no cutting Whereas, the seed quality parameters of the resultant seeds viz., seed germination (89.83\%), seedling vigour index (4168) and seedling dry weight $(0.65 \mathrm{mg})$ was highest in $15^{\text {th }}$ June sowing with no cutting. However, the differences among the treatments were non-significant.

\section{Introduction}

Cowpea (Vigna unguiculata L.) is the most important legume in the world. It is used as fodder, vegetable, pulse and green manure crop. Pulses, popularly known as "poor man's meat", constitute the major source of dietary protein of large section of vegetarian population of the world. On an average, pulse contains 20 to 30 per cent protein. Apart from their high nutritional value, they have a unique characteristic of maintaining and restoring soil fertility through biological nitrogen fixation as well as complete defoliation adding to soil as organic manure thus play a vital role in a sustainable agriculture (Asthana, 1998).

Proper sowing time is the most important nonmonetary input in crop production, which affects the crop growth, yield and quality to 
greater extent. Time of sowing plays an important role to fully exploit all available resources for growth as it provides optimum growing conditions such as temperature, light, humidity and rainfall. Sowing time determines time available for vegetative phase before the onset of flowering, which is mainly influenced by photoperiod. Delay or early sowing may or may not provide the optimum conditions of climate, which results in reduced growth and ultimately affect the yield and quality of produce.

A little variation in sowing time leads to significant changes in performance of the crop. Climate has been changing world over including rainfall onset and distribution has changed and negatively affecting crop productivity in most parts of the world. This has adverse effect on the optimum planting time of crops and results in reduction in the yield.

In almost all legume crops, the asynchrony in pod maturation is a main problem which affects the sustainable agriculture. Many studies were undertaken to overcome this problem and to get synchronized maturity of pods, uniform plant type and seed yield. However, very few studies in different crops were carried out on the influence of haulm cutting on fodder yield and seed yield of cowpea to elucidate the effect of different levels of cuttings on different growth and yield attributing characters. Also the cutting process plays an important role in canopy photosynthesis and source and sink carbohydrates. Hence, the manipulation of plant canopy was undertaken to achieve the non-destructive light enrichment by exposing plant rows to greater light condition. Since, it's the era of dual purpose (fodder yield and seed yield) varieties, experiment on sowing date and haulm cutting will be of great crop in mitigating the fodder (Legume) shortage in the region.

\section{Materials and Methods}

The field experiment was carried out at the ICAR- Indian Grassland and Fodder Research Institute (IGFRI), Southern Regional Research Station, Dharwad during kharif 2017 to evaluate the effect of dates of sowing and haulm cutting on seed yield and quality of fodder cowpea. The experiment was laid out in split plot design with seven treatment combinations viz., $\left(\mathrm{S}_{1}\right.$ : Sown on June $15^{\text {th }}, \mathrm{S}_{2}$ : Sown on July $15^{\text {th }}$ and $\mathrm{S}_{3}$ : Sown on August $\left.15^{\text {th }}\right)$ and four levels of cutting $\left(\mathrm{C}_{1}\right.$ : No cutting, $\mathrm{C}_{2}$ : Haulm cutting at flower initiation, $\mathrm{C}_{3}$ : Haulm cutting at five days after flower initiation and $\mathrm{C}_{4}$ : Haulm cutting at ten days after flower initiation) and replicated thrice. The fodder cowpea seeds (MFC-09-01) were collected from the IGFRI, Dharwad. The cutting of plants was imposed at 6 inches height from the ground. Ten randomly selected and tagged plants from the net plot were used to record the observations. Observations on plant height, branches, leaves, green fodder yield, dry fodder yield, number of pods per plant, seeds per pod, seed yield per plant, seed yield per hectare, germination (\%), seedling vigour index and seedling dry weight were recorded. The growth parameters were recorded at the time of harvesting whereas seed yield and seed quality parameters were recorded after the harvest of the crop data recorded were subjected to the statistical analysis as per Panse and Sukhatme (1967).

\section{Results and Discussion}

\section{Seed yield parameters}

The experiment consisted of three sowing dates viz., sowing on June $15^{\text {th }}$, sowing on July $15^{\text {th }}$ and sowing on August $15^{\text {th }}$ as main plot and four cutting levels viz., control (no cutting), haulm cutting at flower initiation, haulm cutting at 5 days after flower initiation 
and haulm cutting at 10 days after flower initiation as subplot.

Number of pods per plant and number of seeds per pod were significantly influenced by dates of sowing and haulm cutting (Table 1). The early sown crop (June $15^{\text {th }}$ ) significantly recorded maximum number of pods per plant (12.44), highest number of seeds per pod (12.19) and minimum number of pods per plant (10.10), number of seeds per pod (10.41) in (August $15^{\text {th }}$ ). The increase in temperature usually increase photosynthetic rates until photosystem destruction began. The increase in yield attributing parameters under June $15^{\text {th }}$ sowing was due to longer life span, higher dry matter production which has resulted in greater translocation of food materials to the reproductive parts and reflected in superiority of yield attributing parameters (Ram and Dixit, 2001). Similar results of higher seed yield in early sown crop compared to late sown crop were reported by Rima and Nabam (2013) in cowpea and Madhu (2012) in mungbean. Similarly, a greater number of pods per plant (15.28), number of seeds per pod (13.63) recorded with no cut and minimum number of pods per plant (11.51), highest number of seeds per pod (9.99) were recorded in $\mathrm{C}_{4}$. These parameters decreased when the crop was cut at different intervals resulting into inadequate vegetative growth and seed yield. Muro et al., (2001) recorded higher crop yield loss with increasing in level of defoliation in sunflower. $100 \%$ defoliation intensity resulted in lowest seed yield. Since seed number and weight determine yield, yield loss was caused not only by a decrease in vegetative growth but also by the number of pods. Similar findings of yield reduction due to delayed cuts are also reported by several other workers viz., Singh and Kang (2004) and Puri et al., (2007).In interaction maximum number of pods per plant (17.30), highest number of seeds per pod (14.86) recorded in $\mathrm{S}_{1} \mathrm{C}_{1}$ and minimum number of pods per plant
(9.40), highest number of seeds per pod (8.93) in $\mathrm{S}_{3} \mathrm{C}_{4}$.

The pod weight and pod length were significantly influenced by dates of sowing and implication of cutting treatments (Table 1 and 2). The crop seeded on June $15^{\text {th }}$ recorded higher pod length $(14.96 \mathrm{~cm})$ and pod weight $(26.33 \mathrm{~g})$ over the crop seeded on August $15^{\text {th }}$ (11.24 $\mathrm{cm}$ and $23.51 \mathrm{~g}$, respectively).This might be due to early sowing which recorded higher number of leaves per plant, which might have enhanced the area for photosynthesis and efficient utilization of solar energy, the synthesized photosynthates intern might have translocated to reproductive parts. These results are in agreement with findings of Ishwar and Chouhan (1993) in cotton. Among cutting schedules, no cut stage recorded higher pod weight $(29.19 \mathrm{~g})$ and pod length $(14.53 \mathrm{~cm})$ compared to late cut at 10 days after flower initiation $(22.90 \mathrm{~g}$ and 11.51 $\mathrm{cm}$, respectively). Adverse effect of delayed cuttings on pod length and pod weight might be due to disturbance in normal growth, decreased vegetative growth of the plant resulting in less pod weight and pod length. Similar reports were also recorded by Thapa and Maity (2004) in fenugreek. In interaction treatments $\mathrm{S}_{1} \mathrm{C}_{1}$ recorded higher pod length $(16.01 \mathrm{~cm})$ and pod weight $(31.07 \mathrm{~g})$ and minimum pod length $(9.40 \mathrm{~cm})$ and pod weight (21.53 g) in $\mathrm{S}_{3} \mathrm{C}_{4}$.

There were significant differences in 100 seed weight due to dates of sowing and haulm cutting of fodder cowpea (Table 1 and 2). Significantly maximum 100 seed weight was recorded in early sown crop (10.26 g) compared to late sown crop $(9.68 \mathrm{~g})$. The increase in 100 seed weight might be attributed to the favorable climatic conditions, better synthesis and translocation of photosynthates from source to sink, which have enhanced the individual seed weight. These results are in line with the findings of 
Kanaujia et al., (2002) and Gill et al., (2001) in fenugreek. The maximum 100 seed weight was recorded with no cutting (10.93 g) and minimum 100 seed weight $(9.17 \mathrm{~g})$ in late cut crop. Cutting management treatment affected the 100 seed weight which decreased with the delay in cutting period. The higher 100 seed weight noticed without cutting treatment might be due to increase in photosynthetic area leading to higher photosynthetic rate, better assimilation and accumulation of more photosynthates resulting into better seed development as evident with higher test weight. Similar reports were also reported by Gill et al., (2001) in fenugreek. In interaction maximum 100 seed weight $(11.00 \mathrm{~g})$ recorded in $\mathrm{S}_{1} \mathrm{C}_{1}$ and minimum 100 seed weight (8.70 g) recorded in $\mathrm{S}_{2} \mathrm{C}_{4}$.

Dates of sowing and haulm cutting significantly influenced the seed yield per hectare (Table 2). The yield was significantly higher (2.61 q $\mathrm{ha}^{-1}$ ) in first sown crop (June $15^{\text {th }}$ ) and late sown crop recorded lower seed yield $\left(2.39 \mathrm{q} \mathrm{ha}^{-1}\right)$. This might be due to relatively longer life span of crop compared with late sown crop which remained in the field for relatively short duration. These results are in agreement with the findings of Bilal (1994) who reported that late sowing decreased seed yield of mungbean. The highest seed yield (3.92 $\mathrm{q} \mathrm{ha}^{-1}$ ) was recorded in no cut and lowest seed yield (2.01 $\mathrm{q} \mathrm{ha}^{-1}$ ) wad recorded in cut given at 10 days after flower initiation. Cutting time at early growth stage might have disturbed the normal growth of cut plants causing slower re-growth and seed yield per plant, which might have ultimately resulted in higher yield per hectare. These findings are in conformity with Hadi et al., (2012) in barley. Muro et al., (2001) reported that 100 per cent defoliation resulted in lowest seed yield. Since seed number and weight determine yield, yield loss was caused not only by a decrease in vegetative growth but also by the number of pods. The decrease in number of seeds per head with delayed sowing due to reduced growth period was observed by Din et al., (2014). Similar findings of yield reduction due to delayed cuttings are also reported by Puri et al., 2007.In the interaction treatment $S_{1} C_{1}$ recorded maximum seed yield (4.29 $\mathrm{q} \mathrm{ha}^{-1}$ ) and minimum seed yield (1.96 $\left.\mathrm{q} \mathrm{ha}^{-1}\right)$ was recorded in $\mathrm{S}_{3} \mathrm{C}_{4}$.

\section{Seed quality parameters}

Germination percentage, seedling vigour index and seedling dry weight were significantly influenced by dates of sowing and haulm cutting (Table 3 ) The early sowing recorded higher germination $(84.87 \%)$ compared to late sowing $(84.46 \%)$ might be due to proper seed development which is evident through higher 100 seed weight and might have supplied adequate food reserves for resumption of embryonic growth. This is in agreement with the results of Tiparaddi (2003) in sunhemp. The higher germination $(88.93 \%)$ was recorded in early cut $\left(\mathrm{C}_{1}\right)$ compared to late cut $\left(\mathrm{C}_{4}\right)$ recorded lower germination $(82.89 \%)$. The reduction in the germination, root length and shoot length was observed in late cutting treatments was might be due to accumulation of less food reserves in the seeds. These results are in line with Diego et al., (1995) in pearl millet. Among the interactions the treatment combination of S1C1 recorded maximum germination (89.83 $\%)$ and minimum germination (82\%) was recorded in $\mathrm{S} 1 \mathrm{C} 4$.

The seed quality parameters like seedling vigour index (4052) and seedling dry weight $(0.55 \mathrm{mg})$ were recorded maximum in $S_{1}$ whereas minimum seedling vigour index (2996) and seedling dry weight (0.45 mg) was recorded in $\mathrm{S}_{3}$. The increase in seedling vigour and seedling dry weight might be due to increased shoot and root length of the seedling and germination per cent. 
Table.1 Effect of dates of sowing and haulm cutting on number of pods per plant, number of seeds per pod and pod weight of fodder cowpea

\begin{tabular}{|c|c|c|c|}
\hline Treatment details & 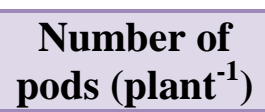 & $\begin{array}{l}\text { Number of } \\
\text { seeds }\left(\operatorname{pod}^{-1}\right)\end{array}$ & $\begin{array}{l}\text { Pod weight } \\
\left(\text { g plant }{ }^{-1}\right)\end{array}$ \\
\hline \multicolumn{4}{|l|}{ Dates of sowing $(\mathrm{S})$} \\
\hline $\begin{array}{l}S_{1}: \text { First sowing on June } 15^{\text {th }} \\
S_{2}: \text { Second sowing on July } 15^{\text {th }} \\
S_{3}: \text { Third sowing in August } 15^{\text {th }}\end{array}$ & $\begin{array}{l}12.44 \\
11.37 \\
10.10\end{array}$ & $\begin{array}{l}12.19 \\
11.43 \\
10.41\end{array}$ & $\begin{array}{l}26.33 \\
25.59 \\
23.51\end{array}$ \\
\hline $\begin{array}{l}\text { S. Em. } \pm \\
\text { C. D. at } 5 \%\end{array}$ & $\begin{array}{l}0.19 \\
0.77\end{array}$ & $\begin{array}{l}0.16 \\
0.64\end{array}$ & $\begin{array}{l}0.43 \\
1.68\end{array}$ \\
\hline \multicolumn{4}{|l|}{ Levels of cuttings (C) } \\
\hline $\begin{array}{l}\mathrm{C}_{1} \text { : Control (No cut) } \\
\mathrm{C}_{2} \text { : Haulm cutting at flower initiation } \\
\mathrm{C}_{3} \text { :Haulm cutting at } 5 \text { days after flower } \\
\text { initiation } \\
\mathrm{C}_{4} \text { : Haulm cutting at } 10 \text { days after flower } \\
\text { initiation }\end{array}$ & $\begin{array}{c}15.28 \\
10.99 \\
10.20 \\
8.76\end{array}$ & $\begin{array}{l}13.63 \\
11.37 \\
10.37 \\
9.99\end{array}$ & $\begin{array}{l}29.19 \\
24.34 \\
24.16 \\
22.90\end{array}$ \\
\hline $\begin{array}{l}\text { S. Em. } \pm \\
\text { C. D. at } 5 \%\end{array}$ & $\begin{array}{l}0.23 \\
0.70\end{array}$ & $\begin{array}{l}0.16 \\
0.47\end{array}$ & $\begin{array}{l}0.57 \\
1.71\end{array}$ \\
\hline \multicolumn{4}{|l|}{ Interaction $(\mathbf{S} \times \mathbf{C})$} \\
\hline $\begin{array}{l}S_{1} C_{1} \\
S_{1} C_{2} \\
S_{1} C_{3} \\
S_{1} C_{4} \\
S_{2} C_{1} \\
S_{2} C_{2} \\
S_{2} C_{3} \\
S_{2} C_{4} \\
S_{3} C_{1} \\
S_{3} C_{2} \\
S_{3} C_{3} \\
S_{3} C_{4}\end{array}$ & $\begin{array}{c}17.30 \\
12.36 \\
11.10 \\
9.00 \\
15.19 \\
10.50 \\
10.03 \\
9.77 \\
13.33 \\
10.10 \\
9.47 \\
7.50\end{array}$ & $\begin{array}{l}14.86 \\
12.03 \\
11.20 \\
10.67 \\
13.52 \\
11.67 \\
10.13 \\
10.38 \\
12.52 \\
10.41 \\
9.77 \\
8.93\end{array}$ & $\begin{array}{l}31.07 \\
25.27 \\
25.00 \\
24.00 \\
29.20 \\
24.89 \\
25.10 \\
23.17 \\
27.30 \\
22.85 \\
22.37 \\
21.53\end{array}$ \\
\hline $\begin{array}{l}\text { S. Em. } \pm \text { for } S \text { at } C \text { levels } \\
\text { C at S levels }\end{array}$ & $\begin{array}{l}0.41 \\
0.64\end{array}$ & $\begin{array}{l}0.27 \\
0.44\end{array}$ & $\begin{array}{l}0.99 \\
1.55\end{array}$ \\
\hline $\begin{array}{l}\text { C. D. at } 5 \% \text { for } \mathrm{S} \text { at } \mathrm{C} \text { levels } \\
\mathrm{C} \text { at } \mathrm{S} \text { levels }\end{array}$ & $\begin{array}{l}1.22 \\
1.98\end{array}$ & $\begin{array}{l}\text { NS } \\
\text { NS }\end{array}$ & $\begin{array}{l}\text { NS* } \\
\text { NS }\end{array}$ \\
\hline
\end{tabular}

*Non-significant 
Table.2 Effect of dates of sowing and haulm cutting on pod length, 100 seeds weight and 1seed yield per hector of fodder cowpea

\begin{tabular}{|c|c|c|c|}
\hline Treatment details & $\begin{array}{l}\text { Pod length } \\
\quad(\mathrm{cm})\end{array}$ & $\begin{array}{c}100 \text { seed } \\
\text { weight }(\mathrm{g})\end{array}$ & $\begin{array}{l}\text { Seed yield } \\
\left(\mathbf{q ~ h ^ { - 1 }}\right)\end{array}$ \\
\hline \multicolumn{4}{|l|}{ Dates of sowing $(\mathrm{S})$} \\
\hline $\begin{array}{l}S_{1}: \text { First sowing on June } 15^{\text {th }} \\
S_{2}: \text { Second sowing on July } 15^{\text {th }} \\
S_{3}: \text { Third sowing in August } 15^{\text {th }}\end{array}$ & $\begin{array}{l}14.96 \\
12.76 \\
11.24\end{array}$ & $\begin{array}{c}10.26 \\
9.68 \\
9.80\end{array}$ & $\begin{array}{l}2.61 \\
2.50 \\
2.39\end{array}$ \\
\hline $\begin{array}{l}\text { S. Em. } \pm \\
\text { C. D. at } 5 \%\end{array}$ & $\begin{array}{l}0.10 \\
0.41\end{array}$ & $\begin{array}{l}0.12 \\
\mathrm{NS}^{*}\end{array}$ & $\begin{array}{l}0.007 \\
0.026\end{array}$ \\
\hline \multicolumn{4}{|l|}{ Levels of cuttings (C) } \\
\hline $\begin{array}{l}C_{1} \text { : Control (No cut) } \\
C_{2} \text { : Haulm cutting at flower initiation } \\
C_{3} \text { :Haulm cutting at } 5 \text { days after flower } \\
\text { initiation } \\
C_{4} \text { : Haulm cutting at } 10 \text { days after flower } \\
\text { initiation }\end{array}$ & $\begin{array}{l}14.53 \\
13.04 \\
12.87 \\
11.51\end{array}$ & $\begin{array}{l}10.93 \\
10.05 \\
9.17 \\
9.50\end{array}$ & $\begin{array}{l}3.92 \\
2.05 \\
2.02 \\
2.01\end{array}$ \\
\hline $\begin{array}{l}\text { S. Em. } \pm \\
\text { C. D. at } 5 \%\end{array}$ & $\begin{array}{l}0.10 \\
0.32\end{array}$ & $\begin{array}{l}0.15 \\
0.46\end{array}$ & $\begin{array}{l}0.010 \\
0.029\end{array}$ \\
\hline \multicolumn{4}{|l|}{ Interaction $(\mathbf{S} \times \mathbf{C})$} \\
\hline $\begin{array}{l}S_{1} C_{1} \\
S_{1} C_{2} \\
S_{1} C_{3} \\
S_{1} C_{4} \\
S_{2} C_{1} \\
S_{2} C_{2} \\
S_{2} C_{3} \\
S_{2} C_{4} \\
S_{3} C_{1} \\
S_{3} C_{2} \\
S_{3} C_{3} \\
S_{3} C_{4}\end{array}$ & $\begin{array}{l}16.01 \\
15.30 \\
15.21 \\
13.33 \\
14.10 \\
12.68 \\
12.46 \\
11.80 \\
13.47 \\
11.12 \\
10.95 \\
9.40\end{array}$ & $\begin{array}{c}11.00 \\
10.50 \\
9.50 \\
10.03 \\
10.99 \\
10.03 \\
9.00 \\
8.70 \\
10.81 \\
9.63 \\
9.00 \\
9.77\end{array}$ & $\begin{array}{l}4.29 \\
2.09 \\
2.04 \\
2.04 \\
3.85 \\
2.07 \\
2.04 \\
2.02 \\
3.63 \\
2.00 \\
1.98 \\
1.96\end{array}$ \\
\hline $\begin{array}{l}\text { S. Em. } \pm \text { for } S \text { at } C \text { levels } \\
C \text { at } S \text { levels }\end{array}$ & $\begin{array}{l}0.19 \\
0.30\end{array}$ & $\begin{array}{l}0.27 \\
0.42\end{array}$ & $\begin{array}{l}0.017 \\
0.026\end{array}$ \\
\hline $\begin{array}{l}\text { C. D. at } 5 \% \text { for } \mathrm{S} \text { at } \mathrm{C} \text { levels } \\
\mathrm{C} \text { at } \mathrm{S} \text { levels }\end{array}$ & $\begin{array}{l}0.56 \\
0.93\end{array}$ & $\begin{array}{l}\text { NS } \\
\text { NS }\end{array}$ & $\begin{array}{l}0.049 \\
0.078\end{array}$ \\
\hline
\end{tabular}

*Non-significant 
Table.3 Effect of dates of sowing and haulm cutting on germination per cent, seedling vigour index and seedling dry weight of fodder cowpea

\begin{tabular}{|c|c|c|c|}
\hline Treatment details & $\begin{array}{c}\text { Germination } \\
(\%)\end{array}$ & $\begin{array}{l}\text { Seedling } \\
\text { vigour } \\
\text { index I }\end{array}$ & $\begin{array}{l}\text { Seedling } \\
\text { dry weight } \\
\text { (mg per } \\
\text { ten plants) }\end{array}$ \\
\hline \multicolumn{4}{|l|}{ Dates of sowing $(\mathrm{S})$} \\
\hline $\begin{array}{l}S_{1}: \text { First sowing on June } 15^{\text {th }} \\
S_{2}: \text { Second sowing on July } 15^{\text {th }} \\
S_{3}: \text { Third sowing in August } 15^{\text {th }}\end{array}$ & $\begin{array}{l}84.87 \\
84.53 \\
84.46\end{array}$ & $\begin{array}{l}4052 \\
3993 \\
2996\end{array}$ & $\begin{array}{l}0.55 \\
0.52 \\
0.45\end{array}$ \\
\hline $\begin{array}{l}\text { S. Em. } \pm \\
\text { C. D. at } 5 \%\end{array}$ & $\begin{array}{l}0.53 \\
\mathrm{NS}^{*}\end{array}$ & $\begin{array}{l}196.08 \\
769.94\end{array}$ & $\begin{array}{l}6.14 \\
\text { NS }\end{array}$ \\
\hline \multicolumn{4}{|l|}{ Levels of cuttings (C) } \\
\hline $\begin{array}{l}\mathrm{C}_{1} \text { : Control (No cut) } \\
\mathrm{C}_{2}: \text { Haulm cutting at flower initiation } \\
\mathrm{C}_{3}: \text { Haulm cutting at } 5 \text { days after flower } \\
\text { initiation } \\
\mathrm{C}_{4} \text { : Haulm cutting at } 10 \text { days after flower } \\
\text { initiation }\end{array}$ & $\begin{array}{l}88.39 \\
84.06 \\
83.14 \\
82.89\end{array}$ & $\begin{array}{l}3861 \\
3690 \\
3616 \\
3555\end{array}$ & $\begin{array}{l}0.60 \\
0.50 \\
0.45 \\
0.48\end{array}$ \\
\hline $\begin{array}{l}\text { S. Em. } \pm \\
\text { C. D. at } 5 \%\end{array}$ & $\begin{array}{l}0.62 \\
1.84\end{array}$ & $\begin{array}{l}141.32 \\
\text { NS }\end{array}$ & $\begin{array}{l}1.09 \\
3.24\end{array}$ \\
\hline \multicolumn{4}{|l|}{ Interaction $(\mathbf{S} \times \mathbf{C})$} \\
\hline $\begin{array}{l}S_{1} C_{1} \\
S_{1} C_{2} \\
S_{1} C_{3} \\
S_{1} C_{4} \\
S_{2} C_{1} \\
S_{2} C_{2} \\
S_{2} C_{3} \\
S_{2} C_{4} \\
S_{3} C_{1} \\
S_{3} C_{2} \\
S_{3} C_{3} \\
S_{3} C_{4}\end{array}$ & $\begin{array}{l}89.83 \\
83.67 \\
82.33 \\
82.00 \\
88.10 \\
84.33 \\
83.00 \\
82.70 \\
87.23 \\
84.17 \\
84.10 \\
83.97\end{array}$ & $\begin{array}{l}4168 \\
4025 \\
4015 \\
4000 \\
4118 \\
4010 \\
3957 \\
3887 \\
3297 \\
3035 \\
2878 \\
2777\end{array}$ & $\begin{array}{l}0.65 \\
0.53 \\
0.43 \\
0.59 \\
0.60 \\
0.51 \\
0.49 \\
0.49 \\
0.56 \\
0.46 \\
0.42 \\
0.36\end{array}$ \\
\hline $\begin{array}{r}\text { S. Em. } \pm \text { for } S \text { at } C \text { levels } \\
C \text { at } S \text { levels }\end{array}$ & $\begin{array}{l}1.07 \\
1.70\end{array}$ & $\begin{array}{l}244.77 \\
416.24\end{array}$ & $\begin{array}{l}1.89 \\
6.76\end{array}$ \\
\hline $\begin{array}{c}\text { C. D. at } 5 \% \text { for } S \text { at } C \text { levels } \\
\text { C at } S \text { levels }\end{array}$ & $\begin{array}{l}\text { NS } \\
\text { NS }\end{array}$ & $\begin{array}{l}\mathrm{NS} \\
\mathrm{NS}\end{array}$ & $\begin{array}{l}\mathrm{NS} \\
\mathrm{NS}\end{array}$ \\
\hline
\end{tabular}

*Non-significant 
As the seedling vigour index is the sum of the shoot and root length of seedling and germination percentage, cumulative effect of these might have resulted in higher vigour values. This is in accordance with the results of Tiparaddi (2003) in sunhemp. Among, in cutting levels $\mathrm{C}_{1}$ recorded higher seedling vigour index (3861) and seedling dry weight (0.60 mg). Minimum seedling vigour index (3555) was recorded in $\mathrm{C}_{4}$. The reduction in the seedling vigor index and seedling dry weight was observed in cutting treatments might be due to accumulation of less food reserves in the seeds. These results are in line with the findings of Vasudevan et al., (2002) in sunflower. However, in interaction maximum seedling vigour index (4168) and seedling dry weight $(0.65 \mathrm{mg})$ were recorded in $\mathrm{S}_{1} \mathrm{C}_{1}$ and minimum seedling vigour index (2777) and seedling dry weight (0.36 mg) was recorded in $\mathrm{S}_{1} \mathrm{C}_{4}, \mathrm{~S}_{3} \mathrm{C}_{4}$ and $\mathrm{S}_{3} \mathrm{C}_{4}$, respectively.

On the basis of experimental research findings, it could be concluded that the sowing dates and cutting levels influenced the seed yield and quality of fodder cowpea. Among the sowing dates, timely sowing (June $15^{\text {th }}$ ) with no cutting enhanced the seed yield and quality.

\section{Acknowledgments}

The authors are thankful to the ICAR- Indian Grassland and Fodder Research Institute, Southern Regional Research Station, Dharwad (Karnataka), India for providing the necessary facilities to undertake the present experiment.

\section{References}

Asthana, A. N., 1998, Pulse crops research in India. Indian J. Agril. Sci., 68(2): 448452.

Bilal, M., 1994, Effect of sowing date and cultivar on the growth and yield of mungbean (Vigna radiata L.). $M . S c$. (Agri.) Thesis, Univ. Agric., Faisalabad. Diego, R., Perez, S. and Martin, G. B., 1995, Effect of liana cutting on water potential and growth of adult Senna mutlijuga (Caesalpinioideae) trees in bolivian tropical forest. J. Biol., 124(2): 469-475.

Din, S., Ullah, I., Khan, G. D., Ramzan, M., Ahmad, B. and Hameed, M., 2014, Sowing dates and irrigation schedule influence on yield and yield components of berseem in district Peshawar. J. Natural Sci. Res., 4(5): 9195.

Gill, B. S., Randhawa, G. S. and Saini, S. S., 2001, Effect of sowing dates and herb cutting management on growth and yield of fenugreek. Indian J. Agron., 46(2): 364-367.

Hadi, F., Hussain, F. and Arif, M., 2012, Effect of different nitrogen levels and cutting on growth behaviour of dual purpose barley (Hordeum vulgare L.). J. Agril. Sci., 2(10): 263-268.

Ishwar, S. and Chouhan, G. S., 1993, Effect of sowing time, cycocel spray and nitrogen fertilization on production potential of upland cotton $(G$. hirsutum). Indian J. Agron., 38(4): 9396.

Kanaujia, V. P., Sachan, C. P. and Thripathi, S. K., 2002, Effect of growth regulators and stratification on germination and vigour of onion (Allium cepa L.) seed. Seed Res., 30(3): 155-157.

Madhu, G., 2012, Response of mungbean (Vigna radiata $\mathrm{L}$. Wilczek) genotypes to dates of sowing and foliar nutrition in kharif season. M. Sc. (Agri.) Thesis, Univ. Agril. Sci., Dharwad, India.

Muro, J. Irigoyen, I., Militino, A. F. and Lamsfus, C., 2001, Defoliation effects on sunflower yield reduction. Agron. J. 93(6): 634-637. 
Panse, U. G. and Sukhatme, 1967, Statistical methods for agricultural workers. ICAR publication, New Delhi, India, pp. 680.

Puri, K. P., Tiwana, U. S. and Bhardwaj. B. L., 2007, Effect of time of last cut on the seed yield of berseem (Trifolium alexandrinum L.). Range Management Agroforestry 28(2): 318-319.

Ram, S. N. and Dixit, R. S., 2001, Effect of dates of sowing and phosphorus on nodulation, uptake of nutrients and yield of summer green gram. Indian J. Agric. Res., 35(4): 275-277.

Rima, T. and Nabam, A. T., 2013, Impact of time of sowing spacing and seed rate on potential seed production and fodder quality of cowpea (Vigna unguiculata
L. Walp). J. Agril. Vet. Sci., 4(4): 61-68. Thapa, U. and Maity, T. K., 2004, Influence of nitrogen, phosphorus and number of cuttings on seed yield fenugreek (Trigonella foenumgraecum L.). Seed Res., 32(1): 33-35.

Tiparaddi, A., 2003, Effect of dates of sowing, spacing and seed rate on seed yield and quality of sunhemp. M. Sc. (Agri) Thesis, Univ. Agric. Sci., Dharwad. pp. 1-89.

Vasudevan, S. N., Sudarshan, J. S., Kurdikeri, M. B. and Dharmatti, P. R., 2002, Influence of pinching of apical bud and chemical sprays on seed yield and quality of fenugreek. Karnataka $J$. Agric. Sci., 21 (1): 26-29.

\section{How to cite this article:}

Basavaraj Benachinamaradi, Vinod Kumar, K. Sridhar and Uppar, D.S. 2019. Effect of Dates of Sowing and Haulm Cutting on Seed Yield and Quality of Fodder Cowpea. Int.J.Curr.Microbiol.App.Sci. 8(07): 335-343. doi: https://doi.org/10.20546/ijcmas.2019.807.041 